\title{
CHANGE-ORIENTED LEADERSHIP : SAFETY COMMITMENT OR PERFORMANCE BEHAVIOR
}

\author{
Muhammad Abdul Jumali ${ }^{1)}$ Eko Budi Utomo ${ }^{2)}$ \\ 1) Program Studi Teknik Industri, Fakultas Teknologi Industri, \\ Universitas PGRI Adi Buana Surabaya \\ Email: abduljumali@unipasby.ac.id
}

\begin{abstract}
Abstrak
Tujuan dari artikel ini untuk mengidentifikasi penyebab resiko pada perusahaan terkait budaya keselamatan berdasarkan pendekatan proses produksi. Metode yang digunakan adalah eksplorasi beberapa data dari sebuah perusahaan X di Surabaya, dikhususkan pada departemen Produksi. Selanjutnya didiskusikan dengan para pimpinan dan yang terkait dengan kinerja produksi. Hasil menunjukkan bahwa penyebab resiko yang dapat membahayakan keselamatan pekerja produksi, dan kebijakan peningkatan kinerja produksi selama ini belum mengedepankan keselamatan pekerja, sehingga dibutuhkan komitmen baru dalam hal keselamatan pekerja. Reorientasi kepemimpinan dalam mengedepankan keselamatan sangat dibutuhkan dalam pembentukan perilaku dan budaya keselamatan di dunia industri. Reorientasi tersebut dilakukan melalui komitmen keselamatan pada level individu, level aturan dan level manajemen.
\end{abstract}

Kata Kunci : Budaya Keselamatan, Komitmen Keselamatan, Perilaku Kinerja

\begin{abstract}
A purpose of this article was to identify causes risks in companies related to safety culture based on the production process approach. The method used is the exploration of some data from a company $X$ in Surabaya, devoted to the production department. Further discussed with the leaders and associated with production performance. Results a causes of risks that could endanger the safety of production workers, and policy of production performance improvement has not yet prioritized the safety of workers, so that a new commitment in terms of worker safety is required. Leadership reorientation in prioritizing safety is needed in the formation of safety behavior and culture in the industrial world. Reorientation is done through safety commitments at the individual level, level of rules and management levels.
\end{abstract}

Keywords : Safety Culture, Safety Commitment, Performance Behaviour 


\section{PENDAHULUAN}

Tema safety culture adalah tema yang sangat menarik karena budaya menjadi bagian penting dalam sebuah perusahaan. Dapat dimaknai bahwa budaya sebagai penjelmaan dari perilaku, sikap dan nilai yang ada dalam organisasi (Blair, 2003; Cooper, 2002; DePasquale dan Geller, 1999), dan menjadi prioritas untuk mencapai safety performance. Cukup banyak kajian yang terkait dengan safety culture pada obyek perusahaan, tetapi kajian safety culture yang telah dilakukan yang lebih banyak memfokuskan pada persoalan lingkungan eksternal, maka penelitian ini dirancang sedemikian rupa untuk memperhatikan aspek komitmen dari para pimpinan, perubahan cara pandang bagi perusahaan. Dengan demikian penelitian ini memberikan sumbangan utama bagi kajian tentang tema budaya keselamatan kerja yang selama ini lebih banyak menjangkau aspek makro.

Kebutuhan peran budaya keselamatan menjadi point penting bagi perusahaan. Hal ini dikarenakan perusahaan menghadapi persaingan yang menuntut perubahan, yakni perubahan perilaku dari pekerja, sehingga akan didapatkan kinerja yang berbasis pada safety. Menjadi sebuah pilihan bagi pimpinan perusahaan, apakah mendahulukan peningkatan kinerja, atau peningkatan kinerja dengan menumbuhkan budaya keselamatan. Begitu juga yang terjadi pada PT. X di Surabaya.

PT. X ini adalah sebuah perusahaan yang bergerak dalam produksi briket arang. Berdasarkan proses produksinya yang memerlukan ketelitian, ketelatenan dan kehati-hatian. Tuntutan dan perubahan lingkungan bisnis mengharuskan perusahaan untuk mampu mewujudkan perilaku kerja individu yang safety. Begitu juga dengan peningkatan daya saing perusahaan diharapkan tidak hanya bisa dicapai melalui upaya meningkatkan produktivitas, tetapi juga dapat dilakukan dengan meningkatkan kualitas, keselamatan, menekan biaya, serta menghilangkan unsur-unsur tidak produktif lainnya. Lebih spesifik, perusahaan harus lebih memperhatikan hal-hal yang berkaitan dengan norma dan standar global yang menyangkut aspek keselamatan kerja, serta isu-isu sensitif lainnya yang berhubungan dengan hak pekerja yaitu memperoleh perlindungan kerja. Perilaku safety menjadi bagian dalam budaya organisasi, dimana memasukkan unsurunsur perilaku, keyakinan, sikap dan nilai-nilai, karena tidak semua anggota organisasi merespon dalam berbagai situasi yang sesuai dengan persepsi organisasi/perusahaan. Kajian atau penelitian tentang perilaku safety pada pelaku/pekerja perusahaan ini sangat diperlukan guna memperkaya wacana dalam rangka menyusun kebijakan dan program penyelesaian masalah yang berkaitan dengan peningkatan perilaku safety di perusahaan. Terlebih pada perubahan cara pandang para pimpinan terhadap persoalan keselamatan kerja.

PT. X di Surabaya ini memproduksi Briket berdasarkan pemesanan (make to order), berdasarkan hal ini maka sudah seyogyanya pekerja pada bagian produksi harus memproduksi sesuai pesanan, sehingga dibutuhkan kualitas kerja yang sesuai standar produk. Dengan demikian, pekerja produksi wajib mempunyai perilaku safety untuk memperoleh hasil kerja yang optimal, dikarenakan proses produksi briket arang tersebut meliputi proses pengambilan bahan baku, pencampuran bahan baku, penyaringan bahan baku, pengeringan bahan baku, penampungan bahan baku, pengepresan menjadi bahan setengah jadi, pendinginan, pengovenan, pendinginan, penyortiran dan penyimpanan. Pada proses produksi ini pekerja produksi dihadapkan pada kondisi/lingkungan kerja yang tidak nyaman, yaitu disebabkan karena suhu udara menjadi lebih panas, asap yang dihasilkan pada proses pembakaran, adanya debu dan sisa pembakaran, dan bau asap yang menyengat.

Data kecelakaan kerja di PT. X menunjukkan bahwa pada 3 (tiga) tahun 
terakhir, jumlah kecelakaan dan tingkat keparahan kecelakaan kerja terus menurun, namun penyebab kecelakaan kerja yang terbanyak adalah karena pekerja tidak mematuhi aturan kerja. Kecelakaan kerja sering terjadi pada Pabrik Briket yang sejenis. Hal ini pada umumnya disebabkan oleh pekerja tidak memenuhi aturan kerja yang telah ditetapkan oleh perusahaan dan pencetakan briket dan pekerja tidak menggunakan pelindung, serta peralatan yang tidak standar.

Kecelakaan kerja juga dipicu jam kerja, dikarenakan frekuensi terjadinya kecelakaan kerja $40 \%$ terjadinya pada pekerja shift 3 , dimana pekerja produksi terbagi menjadi 3 shift, yaitu shift 1 (jam 07.00-15.00 WIB), shift 2 (jam 15.0023.00 WIB), dan shift 3 (jam 23.00$07.00 \mathrm{WIB})$. Adanya pembagian shift tersebut juga memicu terjadinya kecelakaan kerja, dikarenakan pada jam kerja yang masuk pada shift 3 merupakan kumulatif terjadinya kelelahan. Biasanya diawali dengan terbentuknya rasa kantuk serta kelelahan mental, fisik dan atau kelelahan otot yang tergantung dari sifat penyebabnya. Sehingga mengakibatkan berkurangnya kemampuan seseorang dalam bekerja dan mengurangi keselamatan karena tubuh memperlambat respon atau gagal merespon. Jadi hubungan antara kelelahan termasuk siklus tidur (sirkadian), homestatis tidur dan kegiatan yang terkait akan merugikan keselamatan dan penurunan kinerja.

Upaya perusahaan dalam safety, yaitu perusahaan telah menerapkan Sistem Manjemen Keselamatan dan Kesehatan Kerja (K3) hal ini telah sesuai dengan Undang-Undang Ketenagakerjaan Pasal 86 ayat 1 Undang-Undang Ketenagakerjaan Tahun 2003. Kecelakaan kerja berhubungan dengan hubungan kerja di perusahaan. Hubungan kerja dalam hal ini adalah kecelakaan kerja yang terjadi disebabkan oleh karyawan itu atau kesalahan dalam peralatan yang digunakan oleh karyawan pada waktu melaksanakan pekerjaan. Persoalan safety menjadi bagian penting perusahaan untuk diselesaikan, persoalan tersebut disebabkan perilaku pekerja yang tidak memandang faktor safety menjadi faktor penting, artinya pekerja kurang berkomitmen di dalam berperilaku safety, dan iklim kerja safety yang mendukung.

Berdasarkan keyakinan bahwa peningkatan kualitas kerja dihasilkan oleh perilaku safety pekerja dan dapat mendukung peningkatan kualitas proses produksi dan penciptaan budaya safety, maka penelitian ini dirancang sedemikian rupa untuk memfokuskan diri pada mengidentifikasi penyebab resiko pada perusahaan terkait budaya keselamatan berdasarkan pendekatan proses produksi.

\section{METODE}

Penelitian dilakukan dengan pendekatan deskriptif kualitatif. Data dikumpulkan melalui observasi dan diskusi dengan para pimpinan (manajer produksi dan kepala produksi serta supervisor produksi). Keabsahan data diperoleh melalui triangulasi dan kelompok diskusi. Hal ini dilakukan agar diperoleh data yang representatif dan menjawab persoalan serta kebutuhan keselamatan pekerja. Selanjutnya data dianalisis secara induktif dan data disajikan dalam bentuk deskriptif. Variabel dalam artikel ini adalah 1). Komitmen Organisasi, 2). Karakteristik Individu, 3). Budaya Organisasi, 4). Iklim Safety, dan 5). Perilaku Safety.

\section{HASIL DAN PEMBAHASAN}

A. Identifikasi Keselamatan Kerja yang Ada di PT. X Surabaya

PT. X Surabaya adalah perusahaan yang bergerak di bidang briket arang dengan kualitas eksport, yaitu memenuhi pasar briket batubara terutama di Korea, China, dan negara-negara lainnya. Kapasitas produksi arang kayu 850 ton 
per tahun. Kegiatan industri berlokasi di Surabaya dengan luas lahan 10.030 M2 $(1,003 \mathrm{Ha})$.

Perusahaan ini mempunyai tujuan usaha, yaitu memenuhi kebutuhan pasar ekspor briket arang dan meningkatkan produktivitas perusahaan. Kegiatan operasional industri meliputi pemilihan/penyimpanan bahan baku, kegiatan proses produksi, pengemasan hasil produksi, packing dan pengiriman. Dalam melaksanakan proses produksinya tidak hanya bertujuan untuk menghasilkan dan memasarkan produk yang berkualitas, namun dalam aktivitas produksinya, perusahaan juga memfokuskan pada penerapan sistem manajemen yang menjamin mutu, pencegahan pencemaran, dan berbudaya Keselamatan dan Kesehatan Kerja (K3). Perusahaan sudah mulai mengembangkan pendekatan K3 dengan menyertakan aspek perilaku dan budaya (behaviour) selain aspek engineering dan sistem manajemen dalam proses produksi. Hal ini menunjukkan bahwa perusahaan memandang pekerja sebagai asset, dimana asset tersebut dapat ditunjukkan melalui penjaminan terhadap perlindungan dan keselamatan kerja. Dengan menerapkan ketiga aspek perilaku, keteknikan, dan manajemen (behaviour, engineering, management) diharapkan perusahaan mampu meningkatkan kinerja K3 menjadi lebih efektif dan efisien. Nilai-nilai K3 yang dikembangkan perusahaan mampu menggambarkan persepsi pekerja terhadap budaya K3. Aspek - aspek dalam budaya K3 yang diterapkan di perusahaan ini antara lain komitmen manajemen, komunikasi K3 dan kebijakan, peraturan serta pentingnya keselamatan kerja sebagai kebutuhan utama.

Berdasarkan peraturan perusahaan tahun 2012, yang disusun dan diterapkan mulai tahun 2009 menunjukkan keseriusan perusahaan terhadap keselamatan kerja pekerja, menyatakan bahwa dimana karyawan/pekerja berhak mendapatkan perlindungan atas: keselamatan dan kesehatan kerja, moral dan kesusilaan, dan perlakuan sesuai dengan harkat dan martabat manusia serta nilai-nilai keagamaan. Dalam hal ini, dijelaskan juga bahwa untuk melindungi keselamatan karyawan dan kesehatan guna mewujudkan produktivitas kerja yang optimal diselenggarakan upaya keselamatan dan kesehatan kerja yang dilaksanakan berdasarkan peraturan yang berlaku. Pekerja wajib menjaga keselamatan dirinya dan rekan kerja lainnya, wajib memakai alat-alat keselamatan kerja yang disediakan oleh perusahaan serta wajib mengikuti ketentuan keselamatan dan perlindungan kerja yang berlaku. Apabila pekerja menemukan hal-hal yang dapat membahayakan keselamatan pekerja dan perusahaan maka pekerja harus segera melaporkan kepada pimpinan/atasannya.

Dengan berlakunya peraturan tersebut, berarti bahwa perusahaan telah memiliki dan melaksanakan manajemen keselamatan dalam setiap prosedur pelaksanaan kerja. Usaha peningkatan budaya dan perilaku K3 juga sudah diterapkan namun belum secara menyeluruh, fokus budaya K3 masih pada pencegahan serta pengendalian kecelakaan masih sebatas pada persoalan pengadaan mesin dan kebijakan yang didasarkan kinerja semata, belum memfokuskan pada pengendalian melalui pendekatan perilaku karyawan/pekerja. Namun secara umum tingkat kematangan budaya keselamatan pada perusahaan sudah baik. Hal ini menjadi modal dasar untuk mendukung peningkatan budaya dan perilaku K3 yaitu dengan memfokuskan pada pendekatan perilaku dan komitmen para pimpinan yang terkait langsung dengan produksi.

Sasaran dan tujuan PT $X$ yang terkait dengan manajemen penanganan resiko terjadinya kecelakaan kerja dalam proses produksi berdasarkan laporan profil risiko diantaranya:

a. Mampu menghasilkan produk briket arang sesuai dengan standar kualitas dan kuantitas produksi serta persyaratan lingkungan 
dengan mengutamakan aspek safetydalam semua aktifitas,

b. Melaksanakan pengelolaan fungsi lingkungan serta pengawasan norma keselamatan dengan tidak mengabaikan lingkungan, dan melakukan penanggulangan terhadap bahaya kebakaran untuk mencapai kinerja dengan pengelolaan lingkungan bersih, aman dan sehat,

c. Melakukan produksi dengan Zero Accident,

d. Meningkatkan derajat kesejahteraan karyawan,

e. Meningkatkan kehdanalan sarana perlindungan dan penanggulangan resiko yang dihasilkan pada proses produksi,

f. Meminimalisir limbah padat, cair, dan gas

g. Meningkatkan budaya K3 pada karyawan

Berdasarkan sasaran dan tujuan yang telah dibuat, menunjukkan bahwa perusahaan telah berkomitmen untuk mengutamakan keselamatan kerja karyawan melalui memberikan perlindungan, memberikan sarana perlindungan dan membudayakan keselamatan dan kesehatan kerja pada karyawan. Namun tentu saja di dalam aktivitas pekerjaan yang ditemui pekerja, semua aktivitas pekerjaan tersebut mempunyai resiko, apalagi perusahaan bergerak dalam industri briket arang. Resiko pada proses produksi ini mempunyai dampak yang mungkin akan ditemui oleh pekerja, baik dampak langsung maupun dampak jangka panjang.

\section{B. Identifikasi Dampak Resiko Proses Produksi}

Tahap identifikasi dampak resiko dilakukan berdasarkan pada proses produksi briket arang. Identifikasi risiko proses produksi ini dilakukan dengan cara berdiskusi dengan aktor/pelaku yang mengetahui dengan benar kondisi/situasi pada proses produksi yaitu pihak manajemen yang diwakili oleh manajer produksi, supervisor produksi dan perwakilan dari pekerja produksi di area produksi, serta melakukan studi kepustakaan yang bersumber pada data-data dari perusahaan. Diskusi tersebut dilakukan dengan tujuan untuk memperoleh deskripsi atau gambaran kondisi sesungguhnya, sehingga selanjutnya dan dijadikan acuan dalam memetakan dampak dan penanganan dari resiko pekerjaan produksi yang ada. Hasil identifikasi risiko adalah mendata risiko yang memberikan dampak terhadap keberlangsungan sistem produksi yang memicu terjadinya kecelakaan kerja. Setiap sumber risiko dan kejadian risiko dikelompokkan berdasarkan tahapan dalam proses produksinya untuk mempermudah dalam proses identifikasi selanjutnya. Dalam penelitian ini identifikasi dampak risiko didasarkan juga pada laporan Profil Risiko Penyakit Akibat Kerja (PAK). Data mengenai risiko dan dampaknya yang teridentifikasi dapat dilihat pada tabel 1 .

Tabel 1. Identifikasi Resiko dan Dampaknya pada Proses Produksi

\begin{tabular}{ccccc}
\hline No & $\begin{array}{c}\text { Aktivitas } \\
\text { Produksi }\end{array}$ & Kejadian Resiko & $\begin{array}{c}\text { Sumber } \\
\text { Resiko }\end{array}$ & \multicolumn{1}{c}{ Dampak Resiko } \\
\hline & Pemilihan bahan & Terhirup debu & Serbuk kayu & $\begin{array}{l}\text { Terhirup pada } \\
\text { konsentrasi tinggi akan } \\
\text { menyebabkan pusing } \\
\text { kepala, batuk/sesak } \\
\text { pernafasan }\end{array}$ \\
\hline 2 & Screening & Terhirup debu & Serbuk kayu & $\begin{array}{l}\text { Terhirup pada } \\
\text { konsentrasi tinggi akan } \\
\text { menyebabkan pusing }\end{array}$ \\
\hline
\end{tabular}


Muhammad Abdul Jumali \& Eko Budi Utomo : Change-Oriented Leadership : Safety Commitment or Performance Behavior

\begin{tabular}{|c|c|c|c|c|}
\hline No & $\begin{array}{l}\text { Aktivitas } \\
\text { Produksi }\end{array}$ & Kejadian Resiko & $\begin{array}{c}\text { Sumber } \\
\text { Resiko }\end{array}$ & Dampak Resiko \\
\hline & & & & kepala, batuk/sesak \\
\hline & & $\begin{array}{l}\text { Terjepit mesin } \\
\text { screening }\end{array}$ & $\begin{array}{l}\text { Mesin rotary } \\
\text { screen }\end{array}$ & Cedera \\
\hline & & $\begin{array}{l}\text { Terpapar } \\
\text { kebisingan }\end{array}$ & $\begin{array}{l}\text { Mesin rotary } \\
\text { screen }\end{array}$ & $\begin{array}{l}\text { Pendengaran } \\
\text { berkurang/tuli }\end{array}$ \\
\hline \multirow{4}{*}{3} & \multirow{4}{*}{ Drying } & Terhirup debu & Serbuk kayu & $\begin{array}{l}\text { Terhirup pada } \\
\text { konsentrasi tinggi akan } \\
\text { menyebabkan pusing } \\
\text { kepala, batuk/sesak } \\
\text { pernafasan }\end{array}$ \\
\hline & & $\begin{array}{l}\text { Tercium bau sisa } \\
\text { pengeringan }\end{array}$ & $\begin{array}{l}\text { Udara saat } \\
\text { pengeringan }\end{array}$ & $\begin{array}{l}\text { Terhirup pada } \\
\text { konsentrasi tinggi akan } \\
\text { menyebabkan pusing } \\
\text { kepala }\end{array}$ \\
\hline & & $\begin{array}{l}\text { Terpapar } \\
\text { kebisingan }\end{array}$ & Mesin oven & $\begin{array}{l}\text { Pendengaran } \\
\text { berkurang/tuli }\end{array}$ \\
\hline & & Terbakar/meledak & $\begin{array}{l}\text { Mesin oven } \\
\text { yang panas }\end{array}$ & Cedera/kematian \\
\hline \multirow{4}{*}{4} & \multirow{4}{*}{ Exstruding } & $\begin{array}{l}\text { Terhirup gas/debu } \\
\text { polutan }\end{array}$ & $\begin{array}{l}\text { Gas hasil } \\
\text { pengeringan }\end{array}$ & $\begin{array}{l}\text { Terhirup pada } \\
\text { konsentrasi tinggi akan } \\
\text { menyebabkan pusing } \\
\text { kepala, batuk/sesak } \\
\text { pernafasan }\end{array}$ \\
\hline & & $\begin{array}{l}\text { Terjepit mesin } \\
\text { pemadatan }\end{array}$ & $\begin{array}{l}\text { Mesin } \\
\text { exstruder }\end{array}$ & Cedera \\
\hline & & $\begin{array}{l}\text { Terjepit/terluka } \\
\text { akibat mesin press }\end{array}$ & Mesin press & Cedera \\
\hline & & $\begin{array}{l}\text { Terpapar } \\
\text { kebisingan mesin }\end{array}$ & $\begin{array}{l}\text { Mesin } \\
\text { exstruder }\end{array}$ & $\begin{array}{l}\text { Pendengaran } \\
\text { berkurang }\end{array}$ \\
\hline \multirow{4}{*}{5} & \multirow{4}{*}{ Pendinginan } & Terbakar/meledak & $\begin{array}{l}\text { Tungku } \\
\text { pembakaran }\end{array}$ & Cedera/kematian \\
\hline & & Terjepit/terluka & $\begin{array}{l}\text { Tungku } \\
\text { pembakaran }\end{array}$ & Cedera \\
\hline & & $\begin{array}{l}\text { Terpapar panas dan } \\
\text { kebisingan }\end{array}$ & $\begin{array}{l}\text { Carbonizing } \\
\text { oven }\end{array}$ & $\begin{array}{l}\text { Iritasi kulit, dan } \\
\text { pendengaran } \\
\text { berkurang }\end{array}$ \\
\hline & & Terhirup debu & $\begin{array}{l}\text { Debu/uap gas } \\
\text { pendinginan }\end{array}$ & $\begin{array}{l}\text { Pada konsentrasi } \\
\text { tinggi menyebabkan } \\
\text { pusing }\end{array}$ \\
\hline \multirow{2}{*}{6} & \multirow{2}{*}{$\begin{array}{l}\text { Pendinginan } \\
\text { Sortir }\end{array}$} & $\begin{array}{l}\text { Terjepit mesin } \\
\text { pendingin }\end{array}$ & $\begin{array}{l}\text { Mesin } \\
\text { pendingin }\end{array}$ & Cedera \\
\hline & & Terhirup bau & $\begin{array}{l}\text { Bau akibat } \\
\text { briket yang } \\
\text { sudah jadi }\end{array}$ & $\begin{array}{l}\text { Pada konsentrasi } \\
\text { tinggi menyebabkan } \\
\text { pusing }\end{array}$ \\
\hline 7 & Sortir & Terjepit & Mesin Packing & Cedera \\
\hline
\end{tabular}

Berdasarkan tabel 1 dapat diketahui bahwa tiap aktivitas proses produksi mempunyai resiko, karena semua mempunyai sumber resiko. Resiko yang 
paling berbahaya adalah resiko yang berdampak kematian, yaitu ditemui pada aktivitas produksi yang berhubungan dengan proses drying dan karbonisasi. Karena kedua proses ini menggunakan oven pemanas, dan jika penggunaan mesin ini tidak dilakukan dengan hatihati (sembrono) maka mesin oven tersebut bisa meledak. Semua aktivitas produksi mempunyai resiko yang dapat mengganggu kesehatan dan keselamatan kerja, maka dibutuhkan pekerja dengan perilaku yang baik, yaitu perilaku dengan kehati-hatian, mengutamakan faktor safety.

\section{Identifikasi Penyebab Resiko pada Proses Produksi}

Kejadian yang menyebabkan resiko dan memberikan dampak yang telah diidentifikasi, selanjutnya adalah identifikasi penyebab risiko (risk cause) dari suatu kejadian atau yang akan mempengaruhi keselamatan pekerja produksi. Berikut ini data mengenai penyebab munculnya risiko proses produksi ditampilkan dalam tabel 2 .

Tabel 2. Identifikasi Penyebab Risiko pada Proses Produksi

\begin{tabular}{|c|c|c|c|c|}
\hline No & $\begin{array}{l}\text { Aktivitas } \\
\text { Produksi }\end{array}$ & Kejadian Resiko & Sumber Resiko & Penyebab \\
\hline 1 & $\begin{array}{c}\text { Pemilihan bahan } \\
\text { baku }\end{array}$ & Terhirup debu & Serbuk kayu & $\begin{array}{l}\text { Pekerja tidak } \\
\text { menggunakan APD }\end{array}$ \\
\hline \multirow{3}{*}{2} & \multirow{3}{*}{ Screening } & Terhirup debu & Serbuk kayu & $\begin{array}{l}\text { Pekerja tidak } \\
\text { menggunakan APD }\end{array}$ \\
\hline & & $\begin{array}{l}\text { Terjepit mesin } \\
\text { screening }\end{array}$ & $\begin{array}{l}\text { Mesin rotary } \\
\text { screen }\end{array}$ & $\begin{array}{l}\text { Pekerja tidak } \\
\text { menggunakan APD } \\
\text { Adanya proses cleaning } \\
\text { dan perbaikan mesin }\end{array}$ \\
\hline & & $\begin{array}{l}\text { Terpapar } \\
\text { kebisingan }\end{array}$ & $\begin{array}{l}\text { Mesin rotary } \\
\text { screen }\end{array}$ & $\begin{array}{l}\text { Pekerja tidak } \\
\text { menggunakan APD } \\
\text { Akibat performance } \\
\text { equipment yang menurun }\end{array}$ \\
\hline \multirow{4}{*}{3} & \multirow{4}{*}{ Drying } & Terhirup debu & Serbuk kayu & $\begin{array}{l}\text { Pekerja tidak } \\
\text { menggunakan APD }\end{array}$ \\
\hline & & $\begin{array}{l}\text { Tercium bau sisa } \\
\text { pengeringan }\end{array}$ & $\begin{array}{c}\text { Udara saat } \\
\text { pengeringan }\end{array}$ & $\begin{array}{l}\text { Pekerja tidak } \\
\text { menggunakan APD }\end{array}$ \\
\hline & & $\begin{array}{l}\text { Terpapar } \\
\text { kebisingan }\end{array}$ & Mesin oven & $\begin{array}{l}\text { Pekerja tidak } \\
\text { menggunakan APD } \\
\text { Akibat performance } \\
\text { equipment yang menurun }\end{array}$ \\
\hline & & Terbakar/meledak & $\begin{array}{c}\text { Mesin oven yang } \\
\text { panas }\end{array}$ & $\begin{array}{l}\text { Adanya pemicu yang } \\
\text { menimbulkan kebakaran } \\
\text { dan peledakan } \\
\text { Tidak ada safety permit } \\
\text { dalam melakukan } \\
\text { pekerjaan }\end{array}$ \\
\hline \multirow{3}{*}{4} & \multirow{3}{*}{ Exstruding } & $\begin{array}{c}\text { Terhirup gas/debu } \\
\text { polutan }\end{array}$ & $\begin{array}{c}\text { Gas hasil } \\
\text { pengeringan }\end{array}$ & $\begin{array}{l}\text { Pekerja tidak } \\
\text { menggunakan APD }\end{array}$ \\
\hline & & $\begin{array}{l}\text { Terjepit mesin } \\
\text { pemadatan }\end{array}$ & Mesin exstruder & $\begin{array}{l}\text { Pekerja tidak } \\
\text { menggunakan APD } \\
\text { Adanya proses cleaning } \\
\text { dan perbaikan mesin } \\
\end{array}$ \\
\hline & & $\begin{array}{c}\text { Terjepit/terluka } \\
\text { akibat mesin press }\end{array}$ & Mesin press & $\begin{array}{l}\text { Pekerja tidak } \\
\text { menggunakan APD } \\
\text { Adanya proses cleaning }\end{array}$ \\
\hline
\end{tabular}


Muhammad Abdul Jumali \& Eko Budi Utomo : Change-Oriented Leadership : Safety Commitment or Performance Behavior

\begin{tabular}{|c|c|c|c|c|}
\hline No & $\begin{array}{l}\text { Aktivitas } \\
\text { Produksi }\end{array}$ & Kejadian Resiko & Sumber Resiko & Penyebab \\
\hline & & & & dan perbaikan mesin \\
\hline & & $\begin{array}{c}\text { Terpapar } \\
\text { kebisingan mesin }\end{array}$ & Mesin exstruder & $\begin{array}{l}\text { Pekerja tidak } \\
\text { menggunakan APD } \\
\text { Akibat performance } \\
\text { equipment yang menurun }\end{array}$ \\
\hline \multirow{4}{*}{5} & \multirow{4}{*}{ Karbonisasi } & Terhirup gas/debu & $\begin{array}{c}\text { Gas/debu hasil } \\
\text { karbonisasi }\end{array}$ & $\begin{array}{l}\text { Pekerja tidak } \\
\text { menggunakan APD }\end{array}$ \\
\hline & & Terbakar/meledak & $\begin{array}{c}\text { Tungku } \\
\text { pembakaran }\end{array}$ & $\begin{array}{l}\text { Pekerja tidak } \\
\text { menggunakan APD } \\
\text { Adanya pemicu yang } \\
\text { menimbulkan kebakaran } \\
\text { dan peledakan } \\
\text { Tidak ada safety permit } \\
\text { dalam melakukan } \\
\text { pekerjaan }\end{array}$ \\
\hline & & Terjepit/terluka & $\begin{array}{c}\text { Tungku } \\
\text { pembakaran }\end{array}$ & $\begin{array}{l}\text { Pekerja tidak } \\
\text { menggunakan APD }\end{array}$ \\
\hline & & $\begin{array}{c}\text { Terpapar panas dan } \\
\text { kebisingan }\end{array}$ & Carbonizing oven & $\begin{array}{l}\text { Pekerja tidak } \\
\text { menggunakan APD } \\
\text { Akibat performance } \\
\text { equipment yang menurun }\end{array}$ \\
\hline \multirow{2}{*}{6} & \multirow{2}{*}{ Pendinginan } & Terhirup debu & $\begin{array}{c}\text { Debu/uap gas } \\
\text { pendinginan }\end{array}$ & $\begin{array}{l}\text { Pekerja tidak } \\
\text { menggunakan APD }\end{array}$ \\
\hline & & $\begin{array}{c}\text { Terjepit mesin } \\
\text { pendingin }\end{array}$ & Mesin pendingin & $\begin{array}{l}\text { Pekerja tidak } \\
\text { menggunakan APD }\end{array}$ \\
\hline \multirow{2}{*}{7} & \multirow{2}{*}{ Sortir } & Terhirup bau & $\begin{array}{l}\text { Bau akibat briket } \\
\text { yang sudah jadi }\end{array}$ & $\begin{array}{l}\text { Pekerja tidak } \\
\text { menggunakan APD }\end{array}$ \\
\hline & & Terjepit & Mesin Packing & $\begin{array}{l}\text { Pekerja tidak } \\
\text { menggunakan APD }\end{array}$ \\
\hline
\end{tabular}

Sumber : data profil kecelakaan dan penyebab, diolah (2018)

Berdasarkan tabel 2, dapat diperoleh gambaran penyebab resiko pada proses produksi yaitu hampir semua resiko terjadi disebabkan karena perilaku pekerja. Pekerja tidak menggunakan APD adalah penyebab utama, dan safety pada peralatan mesin yang digunakan juga dapat menjadi penyebab terjadinya resiko dari aktivitas produksi yang dilakukan pekerja.

Hasil identifikasi yang telah dilakukan menunjukkan bahwa persoalan perilaku pekerja produksi dalam hal keselamatan kerja menjadi hal penting untuk diselesaikan oleh perusahaan, dan selanjutnya mendiskusikan hal tersebut dengan para pimpinan yang terkait produksi, sehingga hasil diskusi tersebut dapat digunakan dalam rekomendasi sebuah kebijakan, tentu saja kebijakan yang berhubungan dengan keselamatan kerja melalui keseriusan komitmen para pimpinan yang terkait dengan proses produksi.

Perubahan Orientasi
Kepemimpinan : Komitmen pada
Keselamatan Versus Peningkatan
Kinerja
Setelah diketahui bahwa persoalan keselamatan kerja yang ada selama ini 
disebabkan karena perilaku pekerja, maka hasil identifikasi atas temuan tersebut menjadi bahan diskusi dengan para pimpinan. Hasil diskusi selanjutnya menjadi bahan menentukan kebijakan selanjutnya.

Hasil temuan komitmen dari para pimpinan menunjukkan bahwa komitmen diartikan sebagai sikap yang terbentuk karena adanya nilai investasi dalam perusahaan. Temuan ini dapat dijelaskan bahwa menurut Buchanan (dalam Gibson et. al., 1990) mencakup tiga bentuk sikap yaitu: (1) perasaan manunggal dengan tujuan organisasi, (2) perasaan terlibat dalam tugas dan kewajiban keorganisasian, dan (3) perasaan setia kepada organisasi. Sehingga dengan demikian para pimpinan berpendapat bahwa pekerja bagian produksi sebagai keuntungan tersendiri jika mereka memperoleh kinerja yang bagus, sesuai keinginan produksi. Namun, bentuk komitmen yang ada hanya berorientasi pada peningkatan kinerja semata.

Seperti Barney dan Griffin (1996) mengarahkan komitmen pada tiga bentuk yaitu: (1) komitmen terhadap karir yang menekankan pada perkembangan karir individu dalam organisasi atau sejumlah kegiatan yang dilakukan individu yang berorientasi pada karir, (2) komitmen terhadap pekerjaan yang menekankan pada aspek pekerjaan, dan (3) komitmen pada organisasi yang menekankan pada organisasi secara keseluruhan. Pimpinan produksi membentuk komitmen pada penekanan peningkatan kapasitas produksi, namun belum nampak pada penekanan pada aspek pekerjaan, yaitu keselamatan kerja. Meskipun, pimpinan telah mempunyai program keselamatan kerja (K3).

Temuan ini juga menunjukkan bahwa komitmen yang tumbuh pada sikap para pimpinan memenuhi kepentingan organisasi ditunjukkan dalam berbagai bentuk. Hal ini sejalan dengan Luthans (1985) bahwa teradpat tiga aspek utama komitmen pekerja terhadap organisasi yaitu: (1) a strong desire to remain a member of a

particular organization,

williningness to exert highlevel of effort on behalf of the organization, and (3) $a$ definite beliefin dan acceptance of the values dan goals of the organization. Dengan demikian, dapat disimpulkan bahwa komitmen pada dasarnya merupakan orientasi sikap individu terhadap semua obyek yang terdapat dalam perusahaan. Adapun obyek organisasi sebagai orientasi sikap ini diantaranya meliputi karir, pekerjaan, maupun kebijakan organisasi. Jika orientasi individu berorientasi pada karir, maka perilaku atau aktivitas dalam kebijakan pimpiann selalu diarahkan pada perkembangan karir. Sedangkan jika orientasi pimpinan diarahkan pada pekerjaan dan organisasi, maka segala kegiatan individu akan diarahkan pula pada kepentingan organisasi secara keseluruhan.

Untuk mencapai komitmen yang ideal, yang tidak hanya mengutamakan kinerja, namun juga pada keselamatan kerja, maka para pimpinan seharusnya melakukan orientasi kepemimpinan mereka. Yaitu membangun komitmen dengan berbagai cara. Seperti pendapat Kinlaw (1989) bahwa terdapat empat strategi yang dapat diadopsi untuk membentuk sikap komitmen yang kuat yang meliputi langkah-langkah sebagai berikut:

a. Clarity yakni kejelasan terhadap semua nilai dan pekerjaan yang harus dilakukan pimpinan dan pekerja harus mendapat perhatian untuk menumbuhkan komitmen. Tujuan organisasi, nilai, norma, dan peraturan serta serangkaian tugas dan pekerjaan harus dapat dipahami dengan baik dan jelas oleh seluruh pimpinan dan pekerja.

b. Competence yakni bekal kompetensi harus diberikan pimpinan untuk memberi penguatan pimpinan dan pekerja agar memiliki komitmen yang kuat terhadap semua tugas dan pekerjaan yang diberikan perusahaan. Dengan kompetensi pekerja akan terdorong motivasi bekerja serta 
menumbuhkan keyakinan bahwa semua tugas dan pekerjaan akan dapat diselesaikan berdasarkan kemampuan dan kemauannya.

c. Influence yakni komitmen dapat tumbuh semakin kuat jika para pimpinan memiliki pengaruh yang besar terhadap semua bentuk kegiatan kerja pekerja produksi. Setiap pekerja akan memiliki komitmen yang tinggi jika kehadiran atau kerberadaannya dalam perusahaan, kemampuan kerjanya, atau kontribusinya bagi keberhasilan pekerja mendapat perhatian yang proporsional. Perhatian perusahaan secara seksama terhadap semua kegiatan pekerja akan dapat mempengaruhi keaktifan dan kepeduliannya terhadap organisasi.

d. Appreciation atau penghargaan terhadap semua kegiatan yang dilakukan pekerja akan memberi kontribusi yang berarti dalam membangun komitmen. Dengan sekadar mengunjungi pekerja di ruang kerja kemudian menyapa dan mengucapkan terima kasih pada akhir kunjungan akan membawa pengaruh besar bagi tumbuhnya sikap pekerja yang positif dalam tugas-tugasnya.

Selain dengan ke-empat strategi tersebut, komitmen tersebut dapat ditumbuhkan pula melalui serangkaian kebijakan perusahaan yang positif. Dalam hal ini Dessler (1996) menyatakan adanya beberapa cara yang dapat dilakukan untuk menumbukan komitmen organisasi yaitu: promotion from within, (2) a total selection program, (3) orientation dan socialization, (4) empowering work team, (5) helping employee to selfactualize, dan (6) compensation management.

Dengan demikian, reorientasi kepemimpinan ini memandang komitmen keselamatan sebagai poin penting, bukan hanya pada persoalan peningkatan kinerja saja. Selanjutnya, para pimpinan dapat merancang kebijakan yang meliputi penghargaan terhadap pekerja yang berkomitmen safety, sehingga dapat menumbuhkan keikatan pekerja dalam membangun karirnya. Setiap informasi yang menunjukkan kejelasan akan dapat dipahami pekerja sebagai rangsangan yang positif sehingga orientasi dan sosialisasi yang bertujuan memberikan kejelasan tentang kebijakan perusahaan bagi pekerja akan dapat meningkatkan komitmen safety. Adapun penguatan atau pemberdayaan tim kerja merupakan sarana implementasi kebijakan dimana tidak ada satupun pekerjaan yang dapat diselesaikan secara mandiri atau sendiri. Dengan demikian kerja tim dapat pula menumbuhkan komitmen atau keikatan pekerja kepada perusahaan. Nilai lainnya adalah kesediaan pimpinan untuk membantu pekerja dalam mengaktualisasikan diri dalam perusahaan dengan memberikan pekerjaan-pekerjaan yang menantang dikombinasikan dengan skema penggajian yang fair akan dapat pula meningkatkan komitmen safety.

\section{KESIMPULAN}

Sesuai dengan temuan penelitian dan pembahasan, maka diperoleh kesimpulan sebagai berikut :

a. Perusahaan telah memiliki dan melaksanakan manajemen keselamatan dalam setiap prosedur pelaksanaan kerja. Namun belum secara menyeluruh, fokus budaya K3 masih sebatas pada persoalan pengadaan mesin dan kebijakan peningkatan kinerja produksi semata, belum memfokuskan pada keselamatan kerja yang utuh.

b. Semua aktivitas produksi mempunyai resiko yang dapat mengganggu kesehatan dan keselamatan kerja, maka dibutuhkan komitmen semua pihak untuk mengutamakan faktor safety.

c. Komitmen dari para pimpinan dalam membangun budaya safety menunjukkan bahwa komitmen diartikan sebagai sikap yang terbentuk karena adanya nilai investasi dalam perusahaan. 
Sehingga dibutuhkan reorientasi yang meliputi Clarity (kejelasan terhadap semua nilai dan pekerjaan yang harus dilakukan pimpinan dan pekerja harus mendapat perhatian untuk menumbuhkan komitmen), Competence (kompetensi harus diberikan pimpinan untuk memberi penguatan pimpinan dan pekerja agar memiliki komitmen yang kuat terhadap semua tugas dan pekerjaan yang diberikan perusahaan), Influence (para pimpinan memiliki pengaruh yang besar terhadap semua bentuk kegiatan kerja pekerja produksi), dan Appreciation (penghargaan terhadap semua kegiatan yang dilakukan pekerja akan memberi kontribusi yang berarti dalam membangun komitmen).

\section{UCAPAN TERIMA KASIH}

Ucapan terima kasih ditujukan kepada Program Studi Teknik Industri dan Univeristas PGRI Adi Buana Surabaya atas fasilitas laboratorium dalam mendukung penelitian serta Ibu Dr. Anita Kristina, SE., MSi. Atas segala dukungan juga teman diskusi yang baik.

\section{DAFTAR PUSTAKA}

Barney, J.B. and Griffin, R.W. 1996. Management of Organizations: Strategy, Structure, and Behavior. Boston. Houghton Mfifflin Company.

Blair, E. 2003. Culture and Leadership: Seven Key Points for Improved Safety Performance. Professional Safety.(6) : 18-22.

Cooper, D. 2002. Safety culture-A Model for Understanding and Quantifying a Difficult Concept. Professional Safety, vol. 47(6): 3036.

DePasquale, Jason and E. Scott Geller. 1999. Critical Success Faktors for BehaviorBased Safety: A Study of Twenty Industry-Wide Applications. Journal of Safety Research. vol. 30 ( 4 ): 237-249.

Dessler, G. 1996. How to Earn Your Employee's Commitment. Academy of Management Executive. Vol. 13 (2): 58-67.

Gibson, J.L. J.M. Ivancevich, and J.H Donnely, 1997. Organisasi and Manjemen: Perilaku, Struktur and Proses. Jakarta, Penerbit Erlangga.

Kinlaw, D.C. 1989. Coaching for Commitment. New York, Pfeifer and Co.

Luthans, F., 1985. Organizational Behavior (4th ed.). New York, McGraw-Hill Book Company. 